\title{
The Structural Origins of Territorial Stigma: Water and Racial Politics in Metropolitan Detroit
}

\author{
Dana Kornberg \\ University of Michigan \\ Department of Sociology \\ Room 3115 \\ 500 S. State Street
}

Ann Arbor, MI 48109-1382

Email: danakorn@umich.edu

Keywords: Water; territorial stigmatization; Detroit; race; regionalism

\begin{abstract}
This paper develops the concept of territorial stigma by analyzing its cultivation and operation at the level of political institutions that cross municipal divides. To do this, I consider the case of Detroit's regional water department, which has been owned and operated by the City of Detroit and served around 120 suburban regional municipalities. Since the mid-1970s, when the city's first black-led administration took office, the water authority became the main regional institution and an umbilical cord that provided an opportunity for white suburban leaders to organize against the city. Questions of distributing costs were effectively thwarted by white suburban politicians, who blamed rate increases on corruption and incompetency, which reproduced racial stereotypes at the political level while effectively minimizing suburban responsibility for infrastructural legacy costs. The argument builds on the existing literature on territorial stigma by: (1) identifying institutions such as city administrations, and their legalized territories, as sites for the propagation of stigma; and (2) positioning a stigmatized place alongside a valorized one in order to consider them relationally. By doing this, the analysis integrates material-structural and cultural-symbolic factors in order to understand the perpetuation of regional urban inequalities.
\end{abstract}

\section{INTRODUCTION}

We expect water conflicts to develop in arid regions, undersupplied cities, or when municipal services are replaced by corporations; but in metropolitan Detroit - a region that is adjacent to the Great Lakes with one-fifth of the world's fresh water, enjoys a large infrastructure, and has been historically managed by the City of Detroit - why has water become the site of recurring conflict? Unlike in other areas, water politics in metropolitan Detroit have not been motivated by water scarcity, but are instead the result of the legacy costs of overbuilt This is the author manuscript accepted for publication and has undergone full peer review but has not been through the copyediting, typesetting, pagination and proofreading process, which may lead to differences between this version and the Version record. Please cite this article as doi:10.1111/ 1468-2427.12343. 
infrastructure combined with regional balkanization, which results in contests over who should control the flow and shoulder the costs of maintaining expensive infrastructural systems. Instead of a powerful central city using its regional influence to extract resources from subordinate municipalities (Steinberg and Clark, 1999), by historical circumstance a majority-black, relatively poor, and increasingly diminutive city maintained authority over an aging and overbuilt water system that was expanded to serve the suburbs, making an otherwise "boring" (Star, 1999) utility the principal site for regional relations and a key site of aggression.

In the context of Detroit, the primary social cleavages through which water politics have developed are racialized. Yet while urban researchers have documented, the continued presence of racial disparities in housing (e.g. Massey and Denton, 1993; Sugrue, 1996; Turner et al., 2013), employment (Pager, Western, and Bonikowski, 2009; Quillian, 2006: 308), and the location of hazardous waste sites (e.g. Bullard et al., 2008), the racial significance of larger technical systems such as water and sewerage have not been seriously considered. Because of water's sacred properties, and the fact that pipes frequently penetrate otherwise-naturalized boundaries, water infrastructure is an especially fruitful object of study for elucidating social cleavages embedded in relations of power (e.g. Gandy, 2002; Kaika, 2005; Swyngedouw, 2004). Yet the ways that social divides are (re-)produced through the administration of water infrastructures, and the intersection of racial and ethnic cleavages with water, has undergone little serious investigation. Such a perspective is especially useful because U.S. metropolitan areas have experienced increasing levels of inter- rather than intra-municipal segregation since the suburbanization of the 1950 s, which requires a regional perspective on urban inequalities. Simultaneously, anti-black racial biases since the 1960s have been expressed in increasingly 
laissez-faire ways, which necessitates a study of institutions and euphemized language for expressing racial biases.

This paper uses the case of an urban regional infrastructural system in order to demonstrate how the issue of distributing costs across a regional system can become the terrain for a broader a politics of territorial stigmatization - as rhetoric is disseminated through media, and competing politicians work through the courts, legislature, and local governments to shape how a city is characterized. Specifically, I show how suburban charges against the Detroit water department ${ }^{1}$ since the 1970 s have served to reinscribe racial biases through an outwardly "colorblind" and laissez-faire language (Bonilla-Silva, 1997; Bonilla-Silva, 2009; Bobo et al., 1996) that nevertheless drew on racialized tropes in order to perpetuate stigma. By tracing how cultural factors such as perceptions and stereotypes produce and reinforce justifications for social inequality in urban areas, this paper builds on efforts to theorize territorial stigma - the degradation, or stigmatization, of place (Anderson, 2012; Murphy, 2012; Quillian and Pager, 2001; Sampson and Raudenbush, 2004; Wacquant 2007, 2008, 2014; Wilson, 2007) - by: (1) locating institutions, such as city administrations, and their legalized territories as mechanisms for the propagation of stigma in municipal administrations; and (2) considering a stigmatized place (here, the City of Detroit) alongside a valorized one (an alliance of majority-white suburbs) in order to situate them relationally.

${ }^{1}$ The Detroit Water and Sewerage Department system, which was superseded in 2015 by the Great Lakes Water Authority, draws water from two sources on the Detroit River and Lake Huron, after which five water treatment plants distribute water through around 3,400 miles of main pipes using 22 pumping stations and 17 storage reservoirs. Suburban municipalities, which are the department's wholesale customers, receive water from DWSD's mains and send it to individual and commercial users through their own distribution systems, which range in size and complexity depending on population, industry, and fire suppression demands (Detroit Water and Sewerage Department, 2009). 
Why did Detroit's suburbs organize against the city on the matter of water administration, and what have been the effects? To answer these questions, I consider key moments in the history of the Detroit Water and Sewerage Department (DWSD) - particularly when it was expanded in the 1960s and then contested in the 1970s and 2010s - in order to illuminate how white suburban politicians contributed to the city's territorial stigmatization by contesting the department's rates and administrative structure in the legislature, courts, and public sphere. Empirically, I demonstrate how expansion sanctioned under a white-led Detroit administration in the 1950 s and 60s facilitated suburban growth while producing an overbuilt system. After a black mayor took office for the first time in 1974, suburban politicians joined together in an alliance that accused Detroit's administration of predation, incompetence, and danger. By the 2000s, when financial emergency was imminent, these scripts of self-inflicted decline helped to justify the need for outside intervention while city leaders sought to protect their sovereignty. After reviewing the contributions to studies of territorial stigma and the dynamics of color-blind racism below, I move to the evidence, which is presented in three parts.

\section{RACIALIZED INSTITUTIONS AND THE ORIGINS OF TERRITORIAL STIGMA}

Since the 1960s, when many explicitly racially biased practices were banned by law, racial prejudices in the US have become less explicit, instead rooting themselves in outwardly "color blind" claims and ideas (Bobo et al., 1996; Bonilla-Silva, 2009; Lassiter, 2004; for a review see Quillian, 2006). However, the continuing effects of racial discrimination in the US have been documented in a large literature on activities such as job seeking (Pager, Western, and Bonikowski, 2009; Quillian, 2006: 308), housing (Farley et al., 1994; Turner et al., 2013; Massey and Denton, 1993), and traffic arrests (Bates and Fasenfest, 2005), suggesting that 
durable mechanisms continue to perpetuate racial inequalities despite the decreased legitimacy of explicitly racial language (see Bobo \& Charles, 2009 for a review). The persistence of racially biased outcomes prompts us to identify less explicit mechanisms for racially dominant groups to subordinate others in order to maintain their privileged group position (Blumer, 1958). The ideas of "color-blind" and "laissez-faire" racism have been put forward as a way to conceptualize types of racial bias that are not explicit but instead sustained by shared cultural codes expressing racial domination through the language of apolitical market dynamics, individual preferences, or inherent cultural-behavioral limitations (e.g. Bonilla-Silva, 2009; Bobo et al., 1996).

Implicit biases can be applied to territories discursively through popular media and everyday conversation, and when those biases become dominant, places - and the residents within their boundaries - become marked as inferior due to the associated undesirable or dangerous traits (Wacquant et al., 2014; Wacquant, 2007, 2008; Jensen and Christensen, 2012). As a mechanism for grafting ideas of disorder and criminality onto particular spaces, territorial stigma associates residents with damaging characteristics such as criminality, littering, and danger, which become the dominant cultural representation of a place through a process of moving from individual to populations and then finally onto spaces (Murphy, 2012; Quillian and Pager, 2001; Sampson and Raudenbush, 2004; Wacquant, 2007; Wilson, 2007). As Loïc Wacquant describes, due to the taint, places that were once thriving become places of notoriety, where people "commonly hide their address, avoid having family and friends visit them at home, and feel compelled to make excuses for residing in an infamous locale" (2007: 68). Once spaces instead of groups themselves become identified as dangerous, criminal, or disorderly, the social origins of the stigma are obfuscated, and euphemisms allowing for claims of color-blindness can proliferate (cf. Lipsitz, 2011). 
As the primary proponent of territorial stigma as a concept, Wacquant has argued that territorial stigma is produced and diffused through media, state agencies, and ordinary encounters (Wacquant, 2006). Wacquant describes three stages of territorial stigmatization: the fixing of the territory, the disintegration of communities within the territory, and the subsequent loss of social support systems. Territorial stigma, Wacquant explains, is linked to existing sources of stigma - i.e. poverty, race, or immigrant status - but it is not reducible to them (2007: 67), so the stigma exerts related but independent effects on residents within the territory. The stigma exerts negative effects when residents apply for a job or seek a loan from the bank - in addition to the damaging effects the process itself wields by breaking down communities and serving as a justification for heightened police vigilance and criminalization.

Studies of territorial stigma have tended to focus on its effects and responses, with most analyses limited to the scale of the neighborhood (e.g. see special issue of Environment and Planning A 46.6, 2014). How might territorial stigma change when it is operates at the municipal level where it is perpetuated across borders? How are these stigmatizing tropes cultivated, and what purpose do they serve? A key source for the production of territorial stigma, this paper argues, lies at the intersection of political and social (i.e. racial, class-based) antagonisms that allow stereotypes to be applied to state administrations. Locating the origins of territorial stigma is essential because, without specification, the stigma's origins may be attributed to residents' own behaviors by default - potentially becoming fuel for the indirect expression of racial biases. Yet the scholarship so far has focused more on stigma's effects than its sources.

Some researchers, however, have begun to identify the complex roots of territorial stigma, and we have learned that areas may be stigmatized due to the behaviors associated with them (i.e. crime, littering, laziness) or due to the physical attributes of the place itself (i.e. 
overcrowded, dirty, graffiti-ridden), and sources can be located in the state bureaucracy, media, and ordinary perceptions. As Wacquant suggests, studies of territorial stigma may proceed "from below" through ordinary interactions and perceptions, as well as "from above" through media, state, and academic sources (2007: 67).

Studies that look for origins "from below" have tended to focus on the physical attributes of neighborhoods. For example, Alexandra Murphy's (2012) careful ethnographic observations help us to identify the processes whereby poor, black residents of a middle-class US suburb became stigmatized as "litterers" and outsiders, with middle-class residents attributing the litterers' actions to intrinsic traits rather than structural conditions. Similarly, Sampson and Raudenbush (2004) examined perceptions of disorder and found that whites were more likely to report litter, graffiti, drugs, and drinking in public spaces as problems, which exaggerated the amount of physical disorder they recognized compared to their black neighbors. At the micro level, these detailed studies demonstrate the frames that local residents use in order to interpret signs of physical disorder around them and thereby contribute to the territorial stigmatization of neighborhoods.

Studies that take a perspective "from above," on the other hand, have sought to locate the social bases and codes through which territorial stigma is cultivated. For example, Larsen (2014) shows how states may propagate territorial stigma through the unintended results of bureaucratic logics and structures, which results in privileging particular values over others. Glasze et al.'s (2012) also show how cultural codes can vary by context. Using a quantitative discourse analysis of news media, they found that while public housing estates in Germany, France, and Poland were all linked with ideas of threat in news reports, the threat was conceptualized differently in the three countries. Taking a historically comparative perspective, Cohen (2013) traced the 
origins of the Israeli city Bat Yam's stigma to its succession from a majority European Ashkenazi population to predominantly Middle Eastern and North African Mizrahis. Using detailed historical evidence, we learn how the city became coded as crowded, noisy, corrupt, and dangerous once the Mizrahis were the majority. In order to develop the concept of territorial stigma, it is essential to continue to locate the source of the production of the stigma itself, keeping in mind that even though sources may be identified, the stigma continues to wield autonomous efficacy even when the origins are less evident or even altogether diminished.

This paper advances the concept of territorial stigma by demonstrating how it can be cultivated by politicians across legalized borders, which offers a relational perspective that identifies a key source of stigma production outside the territory itself origin. Different from the neighborhood scale, municipal or state boundaries produce more or less independent objects that can subsequently become saturated with meaning so that it becomes logically possible to make statements about entire cities or nations. Instead of the "neighborhoods of exile" that Wacquant describes (2007: 169), cities of exile - of which Detroit is an extreme example - allow stigmatizing associations to become reinforced by the authority of the state. When the state, ripe as it is in symbolic capital, endorses territorially stigmatizing accusations, those characterizations are granted a high level of truth-value (Bourdieu, Wacquant, \& Farage, 1994). Particularly in much of the US, municipalities are granted - and are thus also expected to adhere to - a level of autonomy that makes them responsible for their own political authority, revenue collection practices, and credit ratings. This independence suggests that there are important parallels between the reigning market system, which promotes a system of individual meritocracy, and laissez-faire racism; for both logics deny the racialized sources of inequalities even while they are borne out (Bobo et al., 1997; Mele, 2013; Roberts and Mahtani, 2010; Wilson, 2007). 
Legalized territories - cities, districts, states, or countries - may be characterized in similar ways to stigmatized neighborhood territories, for example as dirty or disorganized, but there are a set of more relevant tropes that may become grafted onto them. Wacquant argues that the rise of territorial stigma in the latter part of the twentieth century was a product of several key political-economic shifts: the 1973 financial crisis, de-industrialization, urban uprisings, suburbanization, and declining federal aid. To this list, however, I add the rise of black urban administrations, which had the bitterly ironic effect of disenfranchising urban residents at the very moment that they were able to exert majority choice. The black mayors who came to power in the mid-1970s and early 1980s across the US may have represented empowerment and hope to the voters who elected them (see, for example, Thompson, 2005), but many white regional and state leaders characterized them as threats from the beginning. This original distrust, and the characterizations that were subsequently launched, allowed suburban leaders to cultivate legitimacy while exerting tangibly damaging effects on the city.

It is this rhetorical strategy - and its enduring effects - that this paper details. Focusing on stereotypical ideas of administrative (in)competence and unsubstantiated charges of corruption allowed suburban leaders to deflect critical questions of costs and resources that may have otherwise been introduced. I locate this dynamic in a case that allows us to identify the structural roots of the cultural stereotypes and demonstrate that they can be perpetuated across municipal divides, which situates the process as a relational one (Bourdieu, 1999: 125). For, symbolic and material goods concentrate in particular places while becoming noticeably absent in others, effectively marking some areas as valorized and others as stigmatized - but always producing them in tandem (Bourdieu, 1999).

In the following sections, I ask: Why did water rate hikes become a key source for 
antagonistic politics between city and suburbs in metropolitan Detroit? What was the impetus for this protest, and what were its immediate and longer-term effects? Answering these questions, I argue, allows us to better understand how structural and cultural factors intersect to reproduce regional divisions. In effect, territorial stigmatization as a relational dynamic can become a vicious cycle of stigmatization and defensiveness that promotes durable regional antagonisms, which serve the interests of the dominant group.

\section{SOURCES OF EVIDENCE}

The argument presented here relies on two forms of evidence. The first includes sources that allowed for the narrative construction of events unfolding over the course of several decades in relation to Detroit's water department. For this purpose, I created an archive that depended on newspaper microfilms for the years 1950s through 1990s and an electronic database for articles beginning in 1999. I compiled a total of 220 relevant articles from The Detroit News between the years 1954 and 1999. Of these, 187 articles were from the years 1976 through 1999, which I located by using the newspaper's print index and selecting articles listed under the subject heading "Detroit Water and Sewerage." I identified an additional 33 articles available on microfilm for the years 1954 through 1976 by using the subject-heading card catalogue available from the Detroit Public Library. From the hundreds of articles listed under this heading, I selected those on issues of rates, administration, regional relations, and legal disputes. While the average number of articles per year (around 5) in my total sample is relatively low, the articles tended to cluster around particularly notable events so that some years would have several relevant articles while others may have none at all - in effect offering a thick description of particularly controversial events on the matters of rates, administration, regional relations, and legal cases. For the years 1999 through 2014, I conducted a search for the same term - "Detroit 
water and sewerage" - in The Detroit News holdings in Proquest Historical Newspapers and scanned more than 750 articles in order to locate the ones that were related to the same criteria applied above. These articles were used in order to reconstruct historical events and identify the dominant rhetorical frames that were relied upon.

The second archive I created in order to address the questions posed above consists of the department's own documents. Although there were no archival records available from the Detroit Water and Sewerage Department (DWSD) after several attempts to locate them through multiple channels, I was able to obtain the department's online material, as well as its annual reports for every year from 1970 through 2011 by filing a Freedom of Information Act request with the City of Detroit. I was able to locate additional reports, ordinances, and financial statements through the Detroit City Clerk's records office. These materials allowed the analysis to take into account how the department's administration and financial accounting intersected with discursive politics. To supplement and substantiate these primary sources, interviews were conducted with two suburban officials and two city officials, and a meeting held with members of the department's finance team.

\section{THE STRUCTURAL PROBLEM: AN OVERBUILT WATER SYSTEM FOR A CHANGING REGION (MID 1950s - MID 1970s)}

The territorial stigmatization that would be cultivated through political antagonisms in the 1970 s had structural roots in an earlier era of suburban expansion, when the Detroit water department issued debt in order to expand the pipes into newly developing suburbs. This expansion resulted in an excessively large regional system that would consequentially require each user to shoulder a higher proportion of its rising costs. Unlike in later years, when white suburban leaders began to accuse the black-run city of mismanaging the system, white leaders 
worked cooperatively across municipal boundaries in the 1950 s to provide water to the growing metropolitan area. In the post-World War II boom years, Detroit leaders planned for population growth that was never realized, and administrators justified the expansion of the water system through a vicious logical circle where expansion necessitated more revenue, which could only be secured through contracting with additional suburban water customers. These were the structural legacies that would inform regional relations in the following decades.

In 1955, the city provided forty-four suburban municipalities with water, who were the department's “wholesale customers.” Between 1956 and 1973, when Gerald J. Remus was director of the department, the system expanded most rapidly in order to serve the sprawling metropolitan region. A key member of Detroit's last white-led administration, Remus was appointed by Republican Mayor Albert E. Cobo, who served from 1950 to 1957 and proclaimed himself to be a protector of white homeowners - having won all of the white-majority city wards in his election but not a single black-majority one (Galster, 2012: 198). Remus' immediate predecessor, Lawrence G. Lenhardt, had called for suburbs to annex themselves into the city in order to get access to Detroit water, but Mayor Cobo replaced Lenhardt with Remus because he favored infrastructure expansion and continuing city control (Movitz and Wright, 1962: 189). Paving the way for expansion, the state legislature consented to lift the limit on the amount of water that could be sold to wholesale customers, allowing fifty-one new suburban municipalities to join the Detroit-run system during Remus' eighteen years as director, bringing the number of municipalities served to ninety-six by the time he departed in 1973 (see Figure 1).

\section{\{Figure 1 here\}}

In order to finance this expansion, the department took on significant sources of debt. In 
1956, just after Lenhardt's departure, the department introduced an $\$ 89$ million $^{2}$ program to build an intake station 60 miles north on Lake Huron and increase existing capacity at its downriver Springwells station in order to boost the system's projected total capacity to 1.24 billion gallons daily by $1970 .{ }^{3}$ The expensive upstream Lake Huron project was justified with promises not only of increased supply and less pollution, but also that the water there would be more wholesome and pure. The investment was described at the time as "immense," but The Detroit News editorial board rationalized the decision with widely accepted contemporary logic: "it has been the history of the local water system that such investments pay for themselves."4

Under Remus' leadership, the department expanded in order to increase revenue and consolidate the city's authority in the region, for which cooperation with regional institutions was necessary. The department published a development plan in 1959, which argued that the utility would thrive only through centralization and expansion: "To gain the best reliability at the lowest cost all of the water for the area should be provided by one system. It must be everexpanding and improving or a system will deteriorate into an antiquated, undependable, and expensive arrangement," the report confidently asserted. ${ }^{5}$ The need for increased water capacity was necessary because a series of water shortages had led to lawn-watering restrictions under Lenhardt, which caused a public outcry (D'Anieri, 2007: 65; Mowitz and Wright 1962: 171). The total cost of the program was estimated to be $\$ 172$ million, which would be financed by the

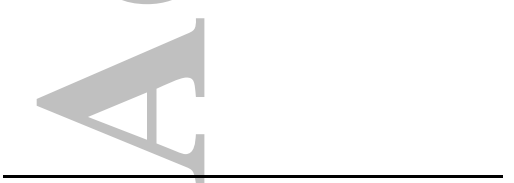

${ }^{2}$ Approximately $\$ 740$ million in 2015 dollars (Consumer Price Index Calculator, <http://data.bls.gov/cgi-bin/cpicalc.pl>)

${ }^{3}$ Carlisle, J M 1956, 'Suburbs to Pay for Water Plan,' The Detroit News 5 June, p. 20.

${ }^{4}$ Carlisle, J M 1956, 'Suburbs to Pay for Water Plan,' The Detroit News 5 June, p. 20.

${ }^{5}$ City of Detroit Board of Water Commissioners (1959) Detroit's Water Development Program for the Metropolitan Area, p. 2. 
city through a combination of income, bonds, and federal grant money. ${ }^{6}$ Indeed, between 1956 and 1968 , city records show that the City of Detroit issued a total of $\$ 147.5$ million in bonds to finance expansion and received at least $\$ 50$ million in federal aid. ${ }^{7}$ Expanding the region's water system was thus justified and funded, without consideration for the fact that the region may not perpetually grow.

However, the 1959 master plan's population projections, which were developed from at least three sources, provide evidence that the city had planned its regional water infrastructure for a much larger future population, which would lead to it being overbuilt, particularly in the city. Planners predicted that the city would remain stable with just under two million people through the year 2000, but that suburban growth - including growth within existing municipalities and in new ones - would be high. If by 1980 the projections were proven inaccurate, with 1.2 million and 2.8 million living in the city and suburbs as against forecasts of 2 million people in the city and 3.2 million in the suburbs, by the year 2000 the numbers deviated more significantly: instead of becoming a region of nearly 7.2 million people in the year 2000 , the Detroit metropolitan area was home to just 4.7 million, or $65 \%$ of the anticipated population (see Table 1). However, once the pipes were in place, the burden was on system users to pay for them - a distributional question that would engender resistance from suburban leaders over the next decade.

\section{\{Table 1 here\}}

Under the leadership of Gerald Remus, the Detroit water system was expanded throughout the region in the 1950s and 60s in order to serve white residents moving to the suburbs, creating

${ }^{6}$ City of Detroit Board of Water Commissioners (1959) Detroit's Water Development Program for the Metropolitan Area, p. 10.

${ }^{7}$ City of Detroit (1970) Ordinance No. 491-G 10 February. Obtained from Detroit City Clerk Archives. 
an extensive network owned and operated by the City of Detroit. During this time, when the city was white-led, city and suburbs worked in partnership to construct the pipes required for Detroit residents to move comfortably into new municipalities. Working together, with both sides agreeing that Detroit could provide water for the suburbs "cheaper than they can provide it for themselves," the system's total capacity was boosted to 760 MGD; 940 by 1960, 1.24 billion GD by $1970 .{ }^{8}$ Water, it seemed at the time, could become the source of a cooperative regional authority. ${ }^{9}$ Instead, however, in the following decades the water department became a primary site of city-suburban conflict.

\section{GENERATING STIGMA TO REDUCE THEIR COSTS: SUBURBAN LEADERS ORGANIZE AGAINST DETROIT (MID 1970s-1980s)}

Cooperation forged in the 1950s would cease by in the 1970s after the surprising victory of Detroit's first black mayor, Coleman Young, in 1973. While suburban leaders partnered with city officials in the 1950 s to build new water intake plants, mains, and pumping stations for increasingly distant suburban developments, once the region had been divided into several majority-white municipalities with a black administration at the center, contests over rates and governance ensued.

By the time Mayor Young took office, the Detroit authority served nearly one hundred suburban municipalities as wholesale customers, but it served 4 million people instead of the 5.5 million that had been projected when the Lake Huron plant was approved. ${ }^{10}$ These twin ingredients - increased costs due to an overbuilt system receiving less federal aid with more federal regulation, along with a black administration at the helm of a regional institution in a

${ }^{8}$ Carlisle, J M 1956, 'Suburbs to Pay for Water Plan,' The Detroit News 5 June, p. 20.

${ }^{9}$ Editorial Board 1954, 'Water, the Key: Pattern for Tomorrow,' The Detroit News 9 August, p. 18.

${ }^{10}$ Ball, D 1975, 'Water Board Won't Share Excess Supply,' The Detroit News 23 March, p. 19A. 
highly segregated and racially charged metropolitan area - would become the sufficient causes triggering resentment and opposition from the area's white leadership, who used the issue to assert racialized positions that protected them from regional responsibilities and curried favor with constituents.

Suburban municipalities contributed to the stigmatization of Detroit in the 1970s and 80s through public claims that: (1) Rates for suburban customers were raised for reasons that were unfair and unjustified, and (2) The Detroit-run department was incompetent and untrustworthy and should be superseded by a suburban-majority water board. They established the first claim via the courts, while the second was broached in the state legislature. When these allegations were echoed through the region's media sources, they became associated with the city itself and contributed to Detroit's stigmatization by marking the city administration - and the city itself as incompetent, corrupt, and dangerous.

The event that provided an immediate cause for suburban leaders to organize was a water rate hike that was proposed in 1975 for the following fiscal year. The budget proposed for the 1975-76 fiscal year totaled $\$ 94.7$ million, up from $\$ 73.8$ million the year before, requiring the first water rate increase since $1972 .{ }^{11}$ At the time, Detroit boasted a water rate that was "the lowest among the nation's large urban areas," but the $39 \%$ increase was a steep rise. ${ }^{12}$ Initial reports did not offer justifications for the rate increase, but later city filings explained that they were precipitated by costs resulting from inflation, which had produced a deficit in the department's budget.

Leading the charge against the rate hike to support a budget that he claimed at the time "almost borders on fraud" was the ambitious white politician Edward H. McNamara, who called

${ }^{11}$ Ball, D 1975, 'Water Board Disavows Proposed Budget,' The Detroit News 11 March, p. B5.

12 Ball, D 1975, 'Water Bill Battle May be Politics,' The Detroit News 29 September, p. B1. 
for a state audit of the department. ${ }^{13}$ Described as a "symbol of suburban frustration" in media reports, ${ }^{14}$ McNamara was up for re-election as mayor of the Wayne County inner-ring, middleclass, and 99\% white suburb of Livonia (Darden et al., 1987: 101) and had been a suburban representative on the water board until he was fired later that year by Mayor Young. ${ }^{15}$ After he was forced out of his position, McNamara took aim at Young through the water issue by organizing 160 officials from the department's 96 suburban municipalities to wage collective action to fight the rate hike. Along with Oakland County Drain Commissioner George Kuhn and Democratic State Representative John Bennett, a front-page newspaper headline announced: "Suburbs to Wage Water Rate Fight."16 McNamara was said to be planning to run for a U.S. Congressional seat the following year, and contemporary reports explained: "there are few easier ways of winning political support in the conservative 2nd District than by playing David to Detroit's Goliath."17

Suburban politicians led by McNamara, Kuhn, and Bennett created a Goliath out of Detroit by characterizing the department's decision to raise rates as unfair and discriminatory and suggesting that the city sought to swindle the suburbs. Democratic State Representative Aldred Sheridan suggested that Detroit residents were directly benefitting from the hike with the complaint: "There is nothing uniform about the water rates, except the ridiculous low prices being paid in the city of Detroit." ${ }^{18}$ Similarly, McNamara claimed that the rate increase, which

${ }^{13}$ Ball, D 1975, 'Water Board Disavows Proposed Budget,' The Detroit News 11 March, p. B5. ${ }^{14}$ Warren, H 1976, 'Suburbs to Wage Water Rate Fight,' The Detroit News 10 February, p. A1. ${ }^{15}$ Warren, H 1976, 'Panel Will Plan Fight Over Water Rates,' The Detroit News 17 February, p. B1.

${ }^{16}$ Warren, H 1976, 'Suburbs to Wage Water Rate Fight,' The Detroit News 10 February, p. A1.

${ }^{17}$ Ball, D 1975, 'Water Bill Battle May be Politics,' The Detroit News 29 September, p. B1.

18 'Suburbs Supported in Bid to Expand Metro Water Board' 1975, The Detroit News 10 July, p. B2. 
was $39 \%$ for both city and suburban customers, was "obviously unwarranted and unnecessary."19 In his letter to Detroit City Council members, McNamara charged that the water department actually had a several million dollar budget surplus but had spent its revenue on new positions that were unnecessary "patronage appointments" with ties to the mayor's office. ${ }^{20}$ However, this was the most specific charge reported at the time. Except for this charge by McNamara, contemporary reports do not identify any particular event or activity being flagged by suburban leaders, instead focusing on more general charges of unjustness and corruption.

Calling itself the Suburban Association of Detroit Water Customers, the group launched a class action lawsuit against the city claiming that the $39 \%$ water rate increase would result in the "unjust enrichment" of the city at the suburbs' expense. ${ }^{21}$ The lawsuit made two claims: first, that the City of Detroit was receiving a rate of return on investment beyond their costs, and second, that the rate hikes were "discriminatory because the suburbs already pay more for pumping and storage costs." 22 As a result of the increases, the plaintiffs charged, the city was realizing "unreasonably high rates of return on investment," which violated the 1957 Michigan law mandating that rates be "reasonably related" to the cost of providing service (Supreme Court of Michigan, 1985).

The attorney on the case, George Ward, elaborated that his suburban clients were seeking \$21 million in damages because "they were overcharged for water so that the city could keep the cost of water service down for its own residents." ${ }^{23}$ Suburban Plymouth's city manager Fred

${ }^{19}$ Roach, R E 1976 'Suburbs Sue to Bar Water Hike' The Detroit News 25 May, p. A1.

${ }^{20}$ Warren, H 1976, 'Suburbs to Wage Water Rate Fight,' The Detroit News 10 February, p. A1.

${ }^{21}$ Roach, R E 1976 'Suburbs Sue to Bar Water Hike' The Detroit News 25 May, p. A1.

22 Roach, R E 1976 'Suburbs Sue to Bar Water Hike' The Detroit News 25 May, p. A1.

${ }^{23}$ Finley, N 1981 'Suburbs May Appeal Water Rates Ruling' The Detroit News 23 November, p. A7. 
Yockey was more explicit: "It's our position that the increase is blatantly inequitable," he charged. $^{24}$ The City of Detroit claimed in its court filing that without the rate increase, the water system would have had a $\$ 1.4$ million deficit for the year, but with the rate increase, the system managed a $\$ 4.6$ million surplus, which could be used for capital improvements. ${ }^{25}$ In fact, even McNamara's hometown of Livonia had raised its customer's rates by $11 \%$ in the same year, with the council similarly citing rising costs due to inflation as the reason for the increase. ${ }^{26}$

The 1976 water rate lawsuit was ultimately ruled in Detroit's favor, but the case was tried in three courts over nine years before the Michigan Supreme Court finally handed down its final decision in 1985. By then, nearly a decade had passed - during which time at least two additional lawsuits were filed by the suburbs, in addition to two federal cases - allowing enough time for the media's coverage to associate the department with greedy exploitation and incompetence. The 1985 state supreme court's decision stated that the lawsuit had been filed despite the fact that there was "general agreement by the parties that the projection of new revenue needs was conservative" (Supreme Court of Michigan, 1985) - needs that were based on anticipated debt reserve requirements and a five-year Capital Improvement Program (CIP) that was to be paid mostly from operating revenue.

The audit results from the 1975 opposition were released in March 1976, and the findings were summarized as follows: “1. It isn't swindling its suburban water and sewer customers. 2. It isn't mishandling its funds. 3. It isn't lying about the need for water and sewer rate increases to avert deficit spending." 27 Without the 1976 increase, the article detailed, the department would

${ }^{24}$ Roach, R E 1976 'Suburbs Sue to Bar Water Hike' The Detroit News 25 May, p. A1.

${ }^{25}$ Roach, R E 1976 'Suburbs Win Access to Water Books' The Detroit News 21 July, p. A3.

${ }^{26}$ Warren, H 1976, 'Water Rate Hiked by Livonia Prior to Detroit Boost,' The Detroit News 30 April, p. BW1.

${ }^{27}$ Ashenfelter, D 1976, 'Audit Backs Boost in Water Rate,' The Detroit News 16 March, p. A3. 
have run a deficit as it had the previous year.

Meanwhile, city officials explained that suburban residents paid much higher rates than the wholesale rate charged by Detroit because local water authorities determined rate and fee structures depending on their own operational and maintenance costs. For example, in 1979 the Detroit department sold water for $\$ 3.11$ per unit to Avon Township, a municipality that was active in the suburban campaign, which subsequently charged its residents $\$ 11.43$ for the same unit of water. ${ }^{28}$ The amount with which each wholesale customer marked up its rates depended not only on their costs, but also on whether they chose to assess fees through water rates, or through other means such as property taxes or new building fees. When the city eventually issued an apology for the 1976 rate hike dispute, the newspaper headline suggested that the apology was for administrative graft, but in fact the city was expressing regret over its poor communication. $^{29}$

In fact, a key area of city-suburban disagreement was the role that debt financing should play in paying for long-term maintenance and repairs. A 1976 city council investigation reported how that year's $39 \%$ rate hike could be cut down to $20 \%$, but the difference would need to be made up with bond revenue. In other words, the decision was not a matter of cutting costs but choosing between debt (via bonds) and revenue (via rates) as sources of capital. ${ }^{30}$ While Director Charles Scales insisted that it was cheaper and therefore better for the city to borrow less money and pay more in cash through revenue, ${ }^{31}$ suburban leaders labeled the department irresponsible

${ }^{28}$ Keith, L 1979, 'House Passes Bill to Cut Young's Power Over Water,' The Detroit News 12 October, p. BDE2.

${ }^{29}$ Ashenfelter, D 1976, 'Water Chief Admits Lapse,' The Detroit News 25 February, p. A8.

${ }^{30}$ Glazier, D 1976, 'Water Rate Hike Can be Halved, Study Says,' The Detroit News 5 May, p. A3.

${ }^{31}$ Roach, R E 1976, “ \$4-Million Water Surplus Predicted in Oakland Court 
for opting not to sell $\$ 25$ million in bonds that were in the budget. ${ }^{32}$ In fact, throughout the 1940s to $60 \mathrm{~s}$, the department had routinely posted revenue surpluses - which the press referred to as "profits" - and these were put toward capital improvements. For example, for fiscal year 196465 , the department posted a "net income" of $\$ 5.6$ million. ${ }^{33}$ At that time, however, there were no related charges of mismanagement or extortion aimed at the department, and the surplus was presented as evidence of responsible administration.

In addition to court action, the suburban group sought legislative approval to shift authority over the department to suburban representatives via majority control on the water board, which created a template for bills that would be introduced by suburban leaders for another two generations. State Representative John Bennett, a Democrat from the inner-ring suburb of Redford Township, where there was not a single black-owned home in 1968 (Darden et al., 1987: 138), introduced three bills to the Michigan House of Representatives in 1976 that would require suburban representation on the water board not be subject to dismissal by the mayor, an annual external audit of the department, and mandatory public hearings to be held before a rate increase is issued. ${ }^{34}$ While the first proposal did not pass, it became a template for successive attempts to gain suburban control via the state legislature over the next four decades.

During the legislative process, suburban leaders cultivated tropes of the city as incompetent, criminal and corrupt. For example, Oakland County Drain Commissioner George Kuhn explained the rationale for the bills in the following way: "The price of incompetence should not be spread on suburban customers who are denied any role in correcting the

\footnotetext{
${ }^{32}$ Warren, H 1976, 'Suburbs to Wage Water Rate Fight,' The Detroit News 10 February, p. A1. 33 'Reported Net Income of \$5.6 Million from Water Sales' 1966, The Detroit News 17 August, p. B18.

${ }^{34}$ Warren, H 1976, 'Suburbs to Wage Water Rate Fight,' The Detroit News 10 February, p. A1.
} 
incompetence. ${ }^{\circledR 3}$ John Maynard, a Democratic State Representative from suburban St. Clair Shores likened the action to a response to violent threat: "We have to make the suburban representatives on the board bulletproof," he described. ${ }^{36}$ The 1976 legislative demands were supported with claims that the city's mismanagement of the system - rather than increasing legacy costs, declining federal aid, and a preference for revenue rather than debt spending - was the reason for the proposed rate increases, which necessitated overhauling the department's administration.

At the center of these racialized stigmatizations was Coleman Young, who was only the city's first black mayor, but also a charismatic and provocative orator who regularly and controversially raised issues of suburban hostility that were couched in the region's racial divides. As the ultimate authority over the water board, which included four city and three suburban members appointed and subject to dismissal by the mayor, Young was a central object of suburban disdain. ${ }^{37}$ Although the administrative system had been in place since 1960, oppositional suburban leaders charged that Young's authority amounted to "one-man rule." ${ }^{38}$ As Detroit became darker and poorer, it also became coded by white leaders as dangerous and dishonest. Demonstrating the aggravation many suburbanites felt at depending on the nowmajority black City of Detroit for water, River Rouge Mayor James Doig commented, "Our hands are tied. We're at their mercy and always have been. We need the water, so we have to pay

\footnotetext{
${ }^{35}$ McClear J A 1979, 'Regional Water-Sewer Council Sought,' The Detroit News 20 December, p. B1.

${ }^{36}$ Keith, L 1979, 'House Passes Bill to Cut Young's Power Over Water,' The Detroit News 12 October, p. BDE2.

${ }^{37}$ In 1960, Detroiters had voted to expand the water board to include suburban members for the first time (Ball, 1975a).

${ }^{38}$ Editorial Board 1977, 'City Must Raise Sewer Rate,' The Detroit News 19 July, p. B4.
} 
whatever they decide. It's out of our hands."39

In a set of political cartoons, city-suburb antagonisms are illustrated through racialized depictions of Mayor Young, who is shown as a threatening figure, armed with a wrench and a gun and threatening to turn off the water in advance of the 1981 rate hikes (Figure 2). In the second image, Young is shown sitting with a shotgun, as if on his front porch, guarding Detroit's infamous Eight Mile Road boundary (Figure 3) - the image suggesting that his armed defensiveness intimidates the white suburban couple innocently walking their dog.

\{Figures 2 and 3 here\}

The suburban unity that was possible after Young's election contrasted with suburban attempts to exert authority over rate setting in the 1950s and 60s. For example, a 1956 proposal had sought to put the water department under the oversight of the Michigan Public Service Commission, which would have regulated rates and expansion plans while allowing the department to issue bonds with lower interest rates. The measure, however, was described benignly as "an attempt to aid local governments, many of which are hard pressed for money to build adequate water supply systems." ${ }^{40}$ In 1966, forty suburban leaders had joined together to support a similar measure, but the group lacked widespread support - viewing Detroit, as they did at the time, as the region's lynchpin rather than a common threat. ${ }^{41}$

Another event at this same time substantially affected the administration of the Detroit water department: in May 1977, the Environmental Protection Agency (EPA) filed a federal lawsuit against the city of Detroit for dumping excessive levels of pollutants into the river. The

${ }^{39}$ Twardon, L and D Bradford 1986, 'Suburbs Bristle Over Detroit Water Rate Changes,' The Detroit News 6 February, p. D1.

40 'Water Board Wants No State Control' 1956, The Detroit News 24 January, p. 18.

${ }^{41}$ Maharry, M 1966, 'State Rule of Detroit's Water Sales Sought,' The Detroit News 26 November, p. 1A. 
outcome of the suit was a consent decree leading to the court appointment of a "special master" to oversee the department, a position that would last for a stunning 36 years and be filled for most of that time by Federal Judge John Feikens. Dubbed the "Sludge Judge," Feikens oversaw plans mandating the construction of expensive pollution abatement mechanisms while restructuring the department to address personnel and procurement issues, while relying more frequently on contractors and consultants than internal staff.

In 1981, the Michigan legislature passed a law that changed how wholesale rates should be calculated by the department. Instead of mandating that they be "reasonable" for the actual service delivered, the law required that rates be "based on the actual cost of service as determined under the utility basis of rate-making. ${ }^{, 42}$ In 1980, the department had contracted the consulting firm Camp Dresser \& McKee to determine how to calculate rates according to this logic, which incorporated revenue requirements along with differences in costs of serving different municipalities. ${ }^{43}$ Based on the American Water Works Association criteria, the new rate structure took into account the "major concerns of suburban wholesale customers regarding cost allocations, unaccounted-for water, and the costs associated with Detroit's retails water distribution system."44 In effect, this basis of accounting addressed the suburban alliance's concerns that they were unfairly shouldering part of the city's own costs, and it created a system where rates would be calculated according to each municipalities actual costs, attempting to cleave closely to a market system of allocation.

${ }^{42}$ Michigan State Act 34 of 1917. Available from http://legislature.mi.gov/doc.aspx?mcl-123141.

${ }^{43}$ Camp Dresser \& McKee 1980, City of Detroit Water and Sewerage Department Proposed Water Rates June. Obtained from Detroit City Clerk Archives.

${ }^{44}$ Camp Dresser \& McKee 1980, City of Detroit Water and Sewerage Department Proposed Water Rates June, pp. 1-1. 
Throughout the late 1970s and early 1980s, suburban charges against the water department administration contributed to characterizations of the City of Detroit as administratively incompetent, discriminatory - and ultimately criminal and corrupt - even when there was no evidence of illegal activity. Instead, by drawing from existing racial stereotypes, white suburban politicians deflected their responsibility to pay for an overbuilt water system and instead blamed city administrators for mismanaging the system and being the sole cause of rising costs.

\section{REALIZING CRISIS IN A STIGMATIZED CITY (1990s-2010s)}

By the 1990s and 2000s, the water system had emerged as a site for the routine stigmatization of Detroit's leadership while the infrastructure proved vastly overbuilt. In 2013, the system pumped less water, 610 millions of gallons daily, than it had in 1954 when it pumped 695 millions of gallons per day, and its peak capacity was enormous: the pipes were capable of sending up to 1700 millions of gallons of water throughout the region, which significantly exceeded actual peak usage of around 900 millions of gallons (Detroit Water and Sewerage Department, 2014; Mowitz and Wright, 1962: 171). ${ }^{45}$ Fewer people and industries paying into a system with an estimated $80 \%$ of its budget dedicated to fixed cost items meant that each person was forced to bear a higher proportion of the department's overhead (Detroit Water and Sewerage Department, 2009: 4), and those who remained in the city bore a higher proportion of the system's fixed costs, paying more on average than suburban residents despite significantly lower average incomes (Butts and Gasteyer, 2011).

\footnotetext{
45 This information was corroborated during a meeting with the department's finance team on 28 October 2014.
} 
Meanwhile, the department's Master Plan of 2004 predicted that “approximately $\$ 4.6$ billion will be needed by the year 2020, largely due to the need to catch up on previously deferred rehabilitation and replacement ( $\mathrm{R}$ and $\mathrm{R})$ of aged infrastructure" (CH2MHill, 2004: 12). The increasing financialization of the department resulted in an organization more highly dependent on debt capital than revenue: whereas in 1970, 30\% of each water revenue dollar was put towards replacements and improvements to the system, by $2010,80 \%$ of each dollar was used for debt service and bond capital financing, demonstrating that the suburban-preferred system of debt financing had indeed succeeded. ${ }^{46}$

Meanwhile, suburban leaders continued to rely on tropes of unfairness, incompetence, and corruption, while many of Detroit's leaders responded to these stigmatizing charges by defending the system as a core city asset and source of economic development. As the city moved into its latest round of "crises" - the conviction of former Detroit Mayor Kwame Kilpatrick on federal charges and state appointment of an Emergency Manager who filed for city bankruptcy - long-standing accusations of mismanagement provided implicit justification for the city's increasingly diminished sovereignty.

In the 1990s and 2000s, a new crop of suburban leaders ascended, inheriting both the rhetorical and tactical approaches of their predecessors. They introduced a steady stream of legislation - in 1993, 1995, 1997, 1999, 2002, 2006, and 2012 - seeking to shift control over the water system to the suburbs and repeatedly challenged rate hikes with allegations of profiteering and mismanagement. Suburban Oakland County Executive L. Brooks Patterson, a leading figure in Michigan politics who built his career on maintaining one of the highest county credit ratings, was essential to the water politics that ensued. Patterson had gained national recognition for

${ }^{46}$ DMWD Annual Report, 1970: 6 and DWSD Summary of Operating Statistics, 2010: 69. Both obtained through a FOIA request to the City of Detroit. 
successfully defending suburban municipalities against regional bussing to promote integration in the Milliken v. Bradley (1974) US Supreme Court case. Continuing claims developed in the 1970s, Patterson interrupted the brief "cease-fire" that had begun when Dennis Archer was elected as mayor in 1994 by explicitly continuing characterizations of the mayor as corrupt: "I don't think (Detroit Mayor Dennis) Archer will be any more willing to give up that cash cow than Coleman Young," he charged, referring to the water department. ${ }^{47}$ Archer, in turn, called suburban attempts to gain majority control over the department had become an "emotional issue" for Detroiters. ${ }^{48}$

Patterson was not alone in his charges against the department. In 2002, leaders from the inner-ring, working-class, and majority-white suburb of Warren fought against the city in court, alleging that the municipality had been overcharged for several years and supported a fresh legislative initiative to gain a suburban majority on the water board. At issue, suburban leaders claimed, was the department's refusal to release its precise rate calculation formula. Warren City Attorney George Constance led the charge in 2002 by supporting the introduction of a bill in the House and publicly serving papers for a lawsuit, which charged the city of failing to provide its formula behind rate hike calculations, implying malfeasance. Constance explained, "There is a lot of interest in Warren and across Macomb County. [...] People are telling us to move forward with our lawsuit because they have felt so powerless for a long time. They are glad someone is taking the bull by the horns." 49

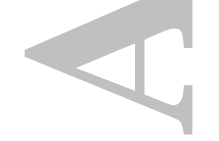

${ }^{47}$ Ourlian, R, Smith, JJ, \& Toy, VS 1995 'Detroit-Suburban Water War Boils,' The Detroit News 19 January, p. B1.

${ }^{48}$ McWhirter, C \& Brand-Williams, O 1999 'Race Frames Detroit-Suburban Battles,' The Detroit News 14 November, p. 1 A.

${ }^{49}$ Schabath, G 2002 'Hearings to Open on Water System,' The Detroit News 8 October, p. 1C. 
Recapitulating charges made in the late 1970s, Patterson accused the Detroit department of discriminating against suburban municipalities. Patterson's rationale for renewing attacks against Detroit were rhetorically "color blind": he claimed to "regionalize the water board and make sure that it is equitable and fair to all" at the recommendation of the county's Business Roundtable. ${ }^{50}$ However, making the board representative of its users would have granted majority-white suburban municipalities, who had been historically united, control over the utility without inheriting the risk of its debt. State Senator Laura Toy, a Republican from Livonia who sponsored the bill in 2006, was clear that while they were seeking greater control over the system, they were not interested in assuming the debt and its attendant risk: "We never wanted to buy into the system, we just wanted another set of eyes and ears on it," she explained. ${ }^{51}$

Calls for a majority-suburban board - whether in assembly or representative form - were also supported with accusations that the city department used its revenue for inappropriate purposes. In 2005, Oakland County Drain Commissioner John P. McCulloch, who was George Kuhn's successor, reportedly "said water rates for suburban cities [...] have been artificially inflated 'for years' and the rate increases are used to underwrite other projects in Detroit rather than just the water system." ${ }^{, 52}$ Department director Victor Mercado countered: "We have had tremendous strides in a productivity increases, reductions in overtime and the overall cost of the system. But the capital improvement is the driving force [...] because you still need to improve the infrastructure." 53

${ }^{50}$ Ourlian, R, Smith, JJ, \& Toy, VS 1995 'Detroit-Suburban Water War Boils,' The Detroit News 19 January, p. B1.

${ }^{51}$ Wisely, J 2006 'Judge: Let Suburbs Buy into Water,' The Detroit News 28 April, p. 1A.

52 Nichols, DA 2005 'Suburban Water Rates to Jump to 5.7\%,' The Detroit News 13 December, p. 1 A.

${ }^{53}$ Nichols, DA 2005 'Suburban Water Rates to Jump to 5.7\%,' The Detroit News 13 December, p. 1 A. 
Suburban claims that they were effectively subsidizing the high number of Detroit residents who were defaulting on their water bills drew on existing characterizations of the department as unfair and exploitative but extended negative administrative stereotypes directly onto Detroit residents. Suburban leaders argued that the department needed to shut off water connections for customers who defaulted on payments - people who were stigmatized in the news as "deadbeats." "54 A series of articles published in 2002 argued that the department had not taken any action to collect the $\$ 59.3$ million it was owed "while imposing big annual rate hikes for paying customers in Detroit and the suburbs." 55 The Deputy Mayor of Warren, Mike Greiner, concluded: "We believe the city of Detroit is completely incapable of managing the water department, and this is just one more example of it." ${ }^{, 56}$ Suburban leaders saw Detroiters' increasing poverty and demolished industrial base as issues for which suburbs should not bear fiscal responsibility, while neoliberal expectations that every municipality be self-sustaining provided legitimacy for their claims.

These debates revealed a divergence in how the department was framed by the suburban alliance and the city. While black leaders in Detroit approached the department as an asset essential to the city's economic development and sovereignty, white suburban leaders took approaches that they claimed to be purely technocratic but worked in their interests by allowing them to deny fiscal responsibility for the city's deepening impoverishment. This became most apparent in debates over contracts, where opponents claimed moral superiority because of their professed "color-blindness" while labeling black Detroiters the perpetrators of racism because they referred to racial categories when expressing an affirmative action policy in hiring and

\footnotetext{
${ }^{54}$ Willcox, C 1978 'Deadbeats Hobble Metro Water Dept.', The Detroit News 11 April, p. B1.

55 Bebow, J 2002 'Unpaid Water Bills in Detroit Top \$59 Million,' The Detroit News, 3 September, p. $1 \mathrm{~A}$.

${ }^{56}$ Wisely, J 2004 'Overdue Water Bills Top \$48 Million,' The Detroit News 22 February, p. 1 A.
} 
contracting. In accordance with City of Detroit policy, the department had aimed to develop the local workforce and award $30 \%$ of contracts and supplies - which totaled around $\$ 400$ million annually - to Detroit-based companies and small firms. ${ }^{57}$ Mary Blackmon, a water board commissioner since 1988, had long framed the department as a mechanism for promoting Detroit's economic development: “This board feels very strongly about equal opportunity for black-owned and Detroit-based businesses. [...] It's not just the bottom financial line here. What does the community get for this? It's power," she explained. ${ }^{58}$

At the same time, L. Brooks Patterson represented the majority opinion of white suburban leaders when he argued that the best way to expand on the number of black-owned businesses was to enact a color-blind procurement policy based on his own county's: "Oakland's procurement system is simple: Companies fill out computerized forms and get bid packets any time a related service is needed. Price - not race or gender - is the determining factor. It's very clean." ${ }^{59}$ Republican State Representative Leon Drolet, took the argument further: "Any time you require people to have a certain skin color to get a contract, those people are the ones who are making it into a racial issue." ${ }^{, 60}$ While Blackmon promoted the department as an important source for the city's economic sustenance and sovereignty, suburban politicians like Patterson and Drolet drew on neoliberal ideas to call for efficiency and transparency via the price mechanism in order to challenge the city's prerogatives.

While suburban proponents of privatizing or regionalizing the water system invoked an outwardly "color-blind" logic of market efficiency because it did not reference racial categories explicitly, Detroit leaders sought to repair their stigmatized status by charging that suburban

\footnotetext{
${ }^{57}$ Bebow, J 2002 'Racial Politics Muddy Water Debate,' The Detroit News, 9 October, p. 1A. 58 Ibid.

59 Ibid.

${ }^{60}$ Ibid.
} 
efforts to gain control over the water system were part of a larger design to wrest power from the black-led city. Detroit NAACP Executive Director Heaster Wheeler confronted his suburban colleagues: "With this water issue and other issues, many black people are wondering: Why are you raping our city? Why are you trying to take governmental control, which is power, from black leaders?"61 Or, as a Detroit City Council Member Kwame Kenyatta elaborated, the water issue affected regional cooperation more generally: "This creates animosity and feelings of racism across the board when it comes to other discussions. Okay now, if I can't have a good relationship with you over the water, then how am I going to have a good relationship with you over transportation?"62 Black leaders have framed suburban opposition as an attack on black sovereignty, which by naming otherwise latent racial biases, invites backlash from white leaders who blame the city for stirring up antagonisms that preclude regional partnerships from forming.

In the 2010s, Detroit was forced to contend with a reputational crisis resulting from the city's former mayor, Kwame Kilpatrick, being convicted of profiting from city contracts. In 2014, Victor Mercado, who had been appointed as director of the water department by Judge Feikens and served under Mayor Kilpatrick, was found guilty of conspiracy for his involvement in steering contracts to Kilpatrick's associates as part of the federal case against Detroit's former mayor. Ironically, the department was under a consent decree that had named Kilpatrick as the special administrator over the department and allowed him to bypass the water board for the approval of contracts and extensions, which he did in order to direct money into the pocket of contractor Bobby Ferguson.

${ }^{61}$ McWhirter, C \& Brand-Williams, O 1999 'Race Frames Detroit-Suburban Battles,' The Detroit News 14 November, p. 1 A.

${ }^{62}$ Interview with Council member Kwame Kenyatta, 13 October 2011. 
This crisis of confidence was soon followed by the imposition of an Emergency Manager in March 2013 by Governor Rick Snyder and a subsequent filing for municipal bankruptcy, which ultimately led to a re-structuring of the water department into a regional authority. The water department graduated from underneath federal oversight in March 2013 for the first time since the 1977 EPA consent agreement. As part of the city's bankruptcy agreement in 2014, the regional Great Lakes Water Authority was created, while an existing plan was underway to eliminate and outsource large parts of the department's workforce in order to reduce expenses and put more revenue toward debt payments (City of Detroit, 2013).

While allegations of the Detroit administration's ineptitude and corruption stem back to the mid-1970s, when there was no evidence cited or found for these claims, events in the 2000s saw these accusations reaching fruition. Suburban leaders continue to assault the city department - amplifying earlier charges claims of biases, profiting, and criminality while city leaders defended the department as a source of economic development - but now those charges were realizing a material reality as Detroit's administration was increasingly supplanted by state and federal oversight. Meanwhile, the vicious cycle of aggressiveness and defensiveness that had been set in motion prevented partnerships from forming across municipal lines, effectively sheltering suburban municipalities from the costs of Detroit's abandonment - and particularly the inherited costs of an overbuilt infrastructure.

\section{DISCUSSION: THE FRUSTRATED REGIONAL POLITICS OF STIGMATIZATION}


Few would dispute that the City of Detroit is an extreme case study in territorial stigmatization. Coleman Young's description of the city as "the blackest, most segregated, most isolated, most restructured, most abandoned, most disenfranchised, most detested, and possibly the most feared city in America" has held for decades, positing Detroit as an exemplary case of territorial stigmatization at the municipal level (Young \& Wheeler, 1994: 325). Territorial stigma, then, can develop from a regional politics where impoverished deindustrialized cities like Detroit become labeled as inept and corrupt, effectively putting responsibility for urban problems onto the city itself and foreclosing larger scales for distributing the fiscal burden.

This pushes the argument for the formation of territorial stigmatization further by demonstrating how territorial stigma can be cultivated through active political campaigns drawing on patterns of racial and ethnic segregation, which contributes to the growing literature on the origins of territorial stigma in bureaucratic structures (Larsen, 2014), media sources (Glasze et al., 2012), and ethnic succession (Cohen, 2013). The paper has sought to identify an important source of territorial stigma in the structural and relational conditions of social divides and state boundaries - which together allow the stigma to be cultivated in order to divert cost distribution questions and make Detroit independently responsible for its abandoned condition.

In this case, the organization of a suburban alliance and use of racialized labels vis-à-vis the water department emerged shortly after Coleman Young took office in 1974, after which an important city department was stigmatized as discriminatory, dangerous, inept, and corrupt codes that drew on existing stereotypes of African Americans but grafted them onto an institution. Although rate hikes were often high - for example the $39 \%$ rise in 1976 - they were met with disproportionate implications of corruption rather than focusing on particular practices. The region's ongoing tendency to attribute city problems to Coleman Young was made apparent 
in a landmark investigative report on the Detroit bankruptcy, which found that Young was the only Detroit mayor to oversee budgets with more revenue than debt since 1950 despite the region's tendency to blame him for Detroit's problems (Bomey \& Gallagher, 2013).

The objective of this analysis has not been to locate the sources of territorial stigma in individual psyches, but rather to identify how the stigma was generated and whom it benefited in other words, its relational social origins and consequences. Here, many of the suburban politicians who collaborated to villainize the department enjoyed successful political careers lasting several decades, suggesting that their actions were widely endorsed in the majority-white region. Moreover, filing long-running court cases and using rhetorical intimidation tactics were useful defenses to employ just as the city was contending with a diminished tax base from commercial and residential abandonment, less federal aid for infrastructure, the 1970s recession, and the expensive requirements of the 1972 Clean Water Act. This politics of intimidation created a deterrent against the city raising rates on suburban customers because increases were likely to lead to allegations of profiteering and corruption, and litigation could take years to resolve. Suburban politicians thus benefited electorally by defaming Detroit, as well as by reducing their responsibility for legacy and regulatory costs.

An example of "real existing regionalism" (Addie \& Keil, 2015), this case combines analyses of discourse, territories, and technologies in order to consider how regions actually operate - acknowledging that they are grounded in their own social contexts and historical experiences. In Michigan, a 1926 act halted the annexation of suburban municipalities, which when combined with existing social cleavages allowed them to maintain relative independence even while other cities were able to incorporate their suburbs (Galster, 2012: 53; Rusk, 2003: 55). The water department is an important site for understanding why regional cooperation has 
so frequently failed in the Detroit metropolitan region. As an explicitly regional enterprise, the department invited suburban assaults against it, suggesting that regional initiatives which operate less publicly may enjoy greater success (D'Anieri, 2007). Indeed, these water disputes, which are a crucial site for understanding the reinforcement of regional divides, have reinscribed racial divisions onto municipal boundaries in an effort to defend the unequal distribution of resources (Omi and Winant, 2008).

The fact that the city's administration was cast as predatory without evidence of maladministration in the 1970s, however, did not mean that real acts of corruption did not occur. However, the politics of stigmatization has a few consequences vis-à-vis actual legal transgressions, or acts of corruption. First of all, stigma allows particular acts of corruption to be re-framed as evidence for more general stereotypes about a particular group. With the cultivation of territorial stigma, the actions of a few are made to represent the group - so that one corrupt administrator from a stigmatized group effectively taints the rest, while their actions are framed as representing the stigmatized population as a whole. Second, once the city was given a stigmatizing label, the cost of administrations actually engaging in those activities decreased, creating the possibility for a self-fulfilling prophecy. Finally, an onslaught of stigmatizing labels may open up opportunities for city leaders to claim to protect residents. In Detroit's case, for example, Kilpatrick was able to use suburban-city antipathy to claim that he was protecting city interests from suburban attack, even while he was squandering public funds through inflated contracts. By focusing political attention on outside aggressors, internal problems may be deemphasized.

The politics of stigma can also lead to a cycle of frustrated regional politics. When the city's water department challenged suburban independence by exerting authority over the 
region's primary umbilical cord and raising rates, the suburbs took the opportunity to organize themselves against the city, setting in motion. The city's assertion of authority was met by organized suburban opposition, which labeled the city administration as incompetent and thieving. In response, city leaders responded defensively to protect their sovereignty and resources, which becomes fresh evidence for suburban characterizations of the city as aggressive (See Figure 4). The stigma effectively associated the city administration with the territory and finally with residents themselves, with characterizations of ineptitude becoming so normalized that actual fraud eventually came to reinforce existing stereotypes. In other words, territorial stigmatization became an influence that "not only denies blacks their rights as citizens but forces them to bear the social costs of their own victimization" (Massey and Denton, 1993: 16).

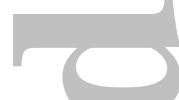

\section{\{Figure 4 here\}}

Part of the process of territorial stigmatization, Wacquant tells us, is that once a place has been deemed criminal, it becomes "easy for the authorities to justify special measures, deviating from both law and custom, which can have the effect - if not the intention - of destabilizing and further marginalizing their occupants" (2007: 69). Wacquant has focused on neighborhood-level criminality, particularly mass incarceration, but this also applies - importantly - to city administrations. For, just as special measures such as militarized policing can be implemented at the neighborhood level, at the municipal scale, the state, national government, or international authority may enter to challenge that territory's authority - its very sovereignty - based on ideas of criminality as corruption.

\section{CONCLUSION}


These established but localized battles over water in Detroit made international headlines in summer 2014, when the city's water department had paid a contractor, Homrich, \$5.6 million to shut off the water connections of 33,607 Detroit customers. ${ }^{63}$ As families ran improvised water pipes into neighbors' houses and community members brought packaged water to homes, activists charged that shutting off water amounted to human rights abuses - for not only were water connections severed, but children were removed from family homes because a water shutoff was reason enough for parents to be classified as unfit in the eyes of the state. In October 2014, two representatives from the United Nations visited the city and added international legitimacy to local activists' claims. ${ }^{64}$ As these events were disseminated via the international media, questions were raised about how this situation could arise in a region that enjoys the greatest freshwater abundance in the world.

As I have argued here, the politics of distribution in Detroit's water department have long been an essential site for the frustrated politics of stigmatization - a cultural politics that has helped suburban residents to avoid shouldering the costs of an overbuilt and increasingly regulated utility in an abandoned and deindustrialized city. Through their organized resistance, suburban leaders have effectively called for a system that charges rates according to a formula to determine actual costs, however difficult those may be to calculate in practice, and effectively deny responsibility for legacy costs and rising city poverty. In a bitter paradox, longstanding suburban accusations that Detroit residents were benefitting from lower rates were effectively

63 Thibodeau, I (2015) After 33,607 water shut-offs in 2014, Detroit to focus on commercial accounts. MLive 17 March <http://www.mlive.com/news/detroit/index.ssf/2015/03/businesses_next_up_for_detroit.html $>$

${ }^{64}$ Gottesdiener, L. (2014) UN officials 'shocked' by Detroit's mass water shutoffs. Al Jazeera America 20 October. <http://america.aljazeera.com/articles/2014/10/20/detroit-waterun.html> 
upended, as thousands of Detroit residents suffered the devastating consequences of the shutoffs when they were unable to afford their bills. Although some causes of the shutoff crisis were more immediate - for instance, the increasing amount of debt due to credit swaps in the early 2000s (Bromey \& Gallagher, 2013) and the desire to demonstrate their will to recoup revenue in the face of neoliberal expectations - many aspects were several decades in the making. For, while the suburbs fought for the city to pay a higher share of the region's costs, Detroit residents were made increasingly responsible for a share of the costs even while they were less able to afford them.

At the broader theoretical level, this paper has argued for recognizing and further investigating how, under what conditions, and with what effects territorial stigma is propagated across administrative boundaries. This paper has demonstrated how the symbolic politics of stigma are cultivated through, and in turn effect, the distribution of critical material resources. Oftentimes, and especially under regimes of euphemization such as the post-1960s US racial landscape, the tropes that are leveraged in order to uphold systems of urban inequality remain implicit and widely accepted. In order to call these out more explicitly, we must continue to identify the historical sources for developing territorial stigmatization and attempt to more explicitly link those sources to their pernicious and enduring effects.

\section{REFERENCES}

Addie, J.P.D. \& R. Keil (2015) Real Existing Regionalism: The Region between Talk, Territory and Technology. International Journal of Urban and Regional Research 39.2, 407-417.

Anderson, E., 2012. The Iconic Ghetto. The ANNALS of the American Academy of Political and Social Science 642.1, 8-24.

Bates, T. and D. Fasenfest (2005) Enforcement Mechanisms Discouraging Black-American Presence in Suburban Detroit. International Journal of Urban and Regional Research 29.4, 960-71.

Blumer, H. (1958) Race Prejudice as a Sense of Group Position. The Pacific Sociological Review 1.1, 3-7. 
Bobo, L.D. \& Charles, C.Z. (2009) Race in the American Mind: From the Moynihan Report to the Obama Candidacy. The ANNALS of the American Academy of Political and Social Science 621.1, 243-259.

Bobo, L., J. R. Kluegel and R. A. Smith (1996) Laissez Faire Racism: The Crystallization of a 'Kinder, Gentler' Anti-Black Ideology. Pp. 15-42 in Racial Attitudes in the 1990s: Continuity and Change. Praeger, Westport.

Bomey, N. \& Gallagher, J. (2013) How Detroit Went Broke. Detroit Free Press. Available at: http://archive.freep.com/interactive/article/20130915/NEWS01/130801004/DetroitBankruptcy-history-1950-debt-pension-revenue.

Bonilla-Silva, E. (1997) Rethinking Racism: Toward a Structural Interpretation. American Sociological Review 62.3, 465-80.

Bonilla-Silva, E. (2009) Racism without Racists: Color-Blind Racism and the Persistence of Racial Inequality in America. Rowman and Littlefield.

Bourdieu, P. (1999) Site Effects. Pp. 123-29 in The Weight of the World: Social Suffering in Contemporary Society, edited by Pierre et al. Bourdieu. Stanford University Press. Stanford.

Bourdieu, P., Wacquant, L. \& Farage, S. (1994) Rethinking the State: Genesis and Structure of the Bureucratic Field. Sociological Theory, 12.1, 1-18.

Bullard, R. D., P. Mohai, R. Saha and B. Wright (2008) Toxic Wastes and Race at Twenty: Why Race Still Matters After All of These Years. Environmental Law 38, 371-411.

Butts, R. and S. Gasteyer (2011) More Cost per Drop: Water Rates, Structural Inequality, and Race in the United States: The Case of Michigan. Environmental Practice 13.4, 386-96.

CH2MHill (2004) Comprehensive Water Master Plan. Prepared for DWSD.

City of Detroit (2013) Proposal for Creditors. Available from http://archive.freep.com/ assets/freep/pdf/C4206913614.pdf.

Cohen, N. (2013) Territorial Stigma Formation in the Israeli City of Bat Yam, 1950-1983: Planning, People and Practice. Journal of Historical Geography 39, 113-124.

D’Anieri, P.J. (2007) Regional Reform in Historic Perspective: Metropolitan Planning Institutions in Detroit, 1950-1990. University of Michigan.

Darden, J. T., R. C. Hill, J. Thomas and R. Thomas (1987) Detroit: Race and Uneven Development. Temple University Press, Philadelphia.

Detroit Water and Sewerage Department (2009) DWSD Rates: A New Regional Paradigm (Working Together to Manage Water Rates).

Detroit Water and Sewerage Department (2014) Facilities. Accessed 18 November 2014. $<$ http://www.dwsd.org/pages_n/facilities_water_treatment.html\#lakehuron>.

Farley, R., C. Steeh, M. Krysan, T. Jackson, and K. Reeves (1994) Stereotypes and Segregation: Neighborhoods in the Detroit Area. American Journal of Sociology 100.3, 750-80.

Galster, G. (2012) Driving Detroit: The Quest for Respect in the Motor City. University of Pennsylvania Press, Philadelphia.

Gandy, M. (2002) Concrete and Clay: Reworking Nature in New York City. MIT Press, Cambridge.

Glasze, G. et al. (2012) "The Same But Not the Same": The Discursive Constitution of Large Housing Estates in Germany, France, and Poland. Urban Geography 33.8, 1192-1211.

Jensen, S. Q. and A. Christensen (2012) Territorial Stigmatization and Local Belonging. City 16.1-2, 74-92.

Kaika, M. (2005) City of Flows: Nature, Modernity, and the City. Routledge, New York. 
Larsen, T.S. (2014) Copenhagen's West End a "Paradise Lost": The Political Production of Territorial Stigmatization in Denmark. Environment and Planning A, 46.6, 1386-1402.

Lassiter, M. D. (2004) The Suburban Origins of 'Color-Blind' Conservatism: Middle-Class Consciousness in the Charlotte Busing Crisis. Journal of Urban History 30.4, 549-82.

Lipsitz, G. (2011) How Racism Takes Place. Temple University Press, Philadelphia.

Massey, D. S. and N. A. Denton (1993) American Apartheid: Segregation and the Making of the Underclass. Harvard University Press, Cambridge.

Mele, C. (2013) Neoliberalism, Race and the Redefining of Urban Redevelopment. International Journal of Urban and Regional Research 37.2, 598-617.

Mowitz, R.J. \& Wright, D.S. (1962) Profile of a Metropolis, Detroit: Wayne State University Press.

Murphy, A. K. (2012) 'Litterers': How Objects of Physical Disorder Are Used to Construct Subjects of Social Disorder in a Suburb. The ANNALS of the American Academy of Political and Social Science 642.1, 210-27.

Omi, M. and H. Winant (2008) Once More, with Feeling: Reflections on Racial Formation. Proceedings of the Modern Language Association 123.5, 1566-72.

Pager, D., B. Western and B. Bonikowski (2009) Discrimination in a Low-Wage Labor Market: A Field Experiment. American Sociological Review 74.5, 777-99.

Quillian, L. (2006) New Approaches to Understanding Racial Prejudice and Discrimination. Annual Review of Sociology 32, 299-328.

Quillian, L. and D. Pager (2001) Black Neighbors, Higher Crime? The Role of Racial Stereotypes in Evaluations of Neighborhood Crime. American Journal of Sociology 107.3, 717-67.

Roberts, D. J. and M. Mahtani (2010) Neoliberalizing Race, Racing Neoliberalism: Placing 'Race' in Neoliberal Discourses. Antipode 42.2, 248-57.

Rusk, D. (2003) Cities Without Suburbs, Washington, D.C.: Woodrow Wilson Center Press.

Sampson, R. J. and S. W. Raudenbush (2004) Seeing Disorder: Neighborhood Stigma and the Social Construction of 'Broken Windows.' Social Psychology Quarterly 67.4, 319-42.

Star, S.L. (1999) The Ethnography of Infrastructure. American Behavioral Scientist, 43.3, 377391.

Steinberg, P. E. and G. E. Clark (1999) Troubled Water? Acquiescence, Conflict, and the Politics of Place in Watershed Management. Political Geography 18, 477-508.

Sugrue, T. J. (1996) The Origins of the Urban Crisis: Race and Inequality in Postwar Detroit. Princeton University Press.

Swyngedouw, E. (2004) Social Power and the Urbanization of Water: Flows of Power. Oxford University Press, Oxford.

Thompson, J. P. III (2005) Double Trouble: Black Mayors, Black Communities, and the Call for a Deep Democracy, New York: Oxford University Press.

Turner, M. A., R. Santos, D. K. Levy, D. A. Wissoker, C. Aranda and R. Pitingolo (2013) Housing Discrimination against Racial and Ethnic Minorities 2012. U.S. Department of Housing and Urban Development.

Wacquant, L. (2007) Territorial Stigmatization in the Age of Advanced Marginality. Thesis Eleven 91.1, 66-77.

Wacquant, L. (2008) Urban Outcasts: A Comparative Sociology of Advanced Marginality. Polity, Cambridge. 
Wacquant, L., T. Slater and V. B. Pereira. (2014) Territorial Stigmatization in Action. Environment and Planning A 46.6, 1270-80.

Wilson, D. (2007) Cities and Race: America's New Black Ghetto. Routledge, New York.

Young, C. \& Wheeler, L. (1994) Hard Stuff: The Autobiography of Mayor Coleman Young, Viking Adult.
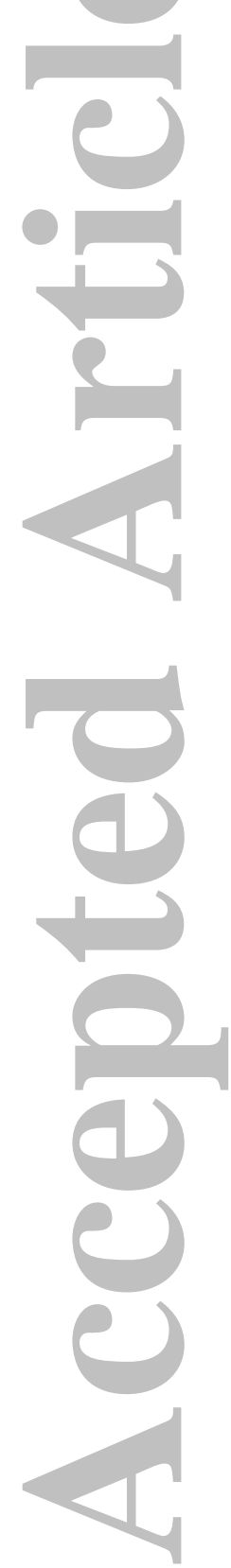
Table 1: 1959 total population planning projections compared with actual census data (in millions):

\begin{tabular}{|c|c|c|c|c|c|c|}
\hline & \multicolumn{3}{|c|}{1959 PROJECTIONS $^{1}$} & \multicolumn{3}{|c|}{ ACTUAL POPULATION ${ }^{2}$} \\
\hline & City $^{3}$ & Suburbs $^{4}$ & Region & City & Suburbs & Region \\
\hline 1960 & 1.93 & 1.47 & 3.40 & 1.67 & 2.09 & 3.76 \\
\hline 1970 & 1.98 & 2.39 & 4.37 & 1.51 & 2.69 & 4.20 \\
\hline 1980 & 1.96 & 3.21 & 5.17 & 1.20 & 2.84 & 4.04 \\
\hline 2000 & 1.96 & 5.19 & 7.15 & 0.95 & 3.73 & 4.68 \\
\hline
\end{tabular}
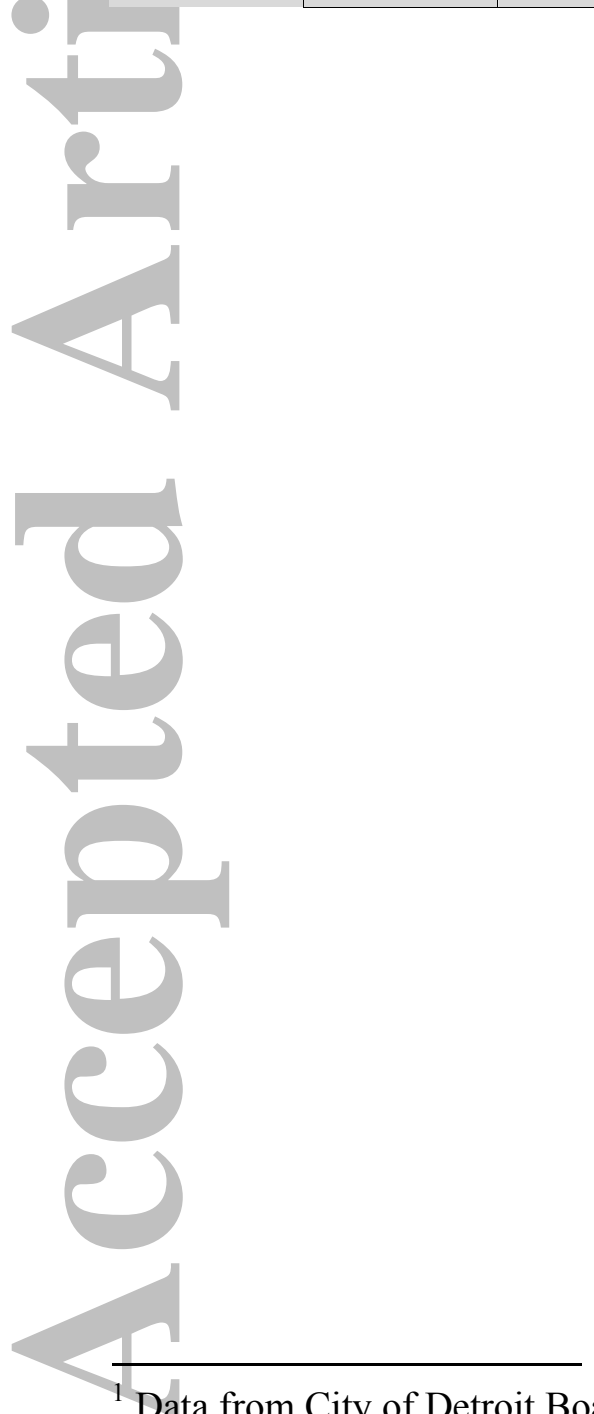

'Data from City of Detroit Board of Water Commissioners. 1959. Detroit's Water Development Program for the Metropolitan Area. P. 9

${ }^{2}$ Data is from the U.S. Census (accessed via Social Explorer) for the years mentioned.

${ }^{3}$ Includes only the city of Detroit.

${ }^{4}$ The years 1960, 1970, 1980 include Macomb, Oakland, and Wayne counties. The year 2000 includes Macomb, Monroe, Oakland, St. Clair, Washtenaw, and Wayne counties because the 1959 predictions include those areas for those years. 


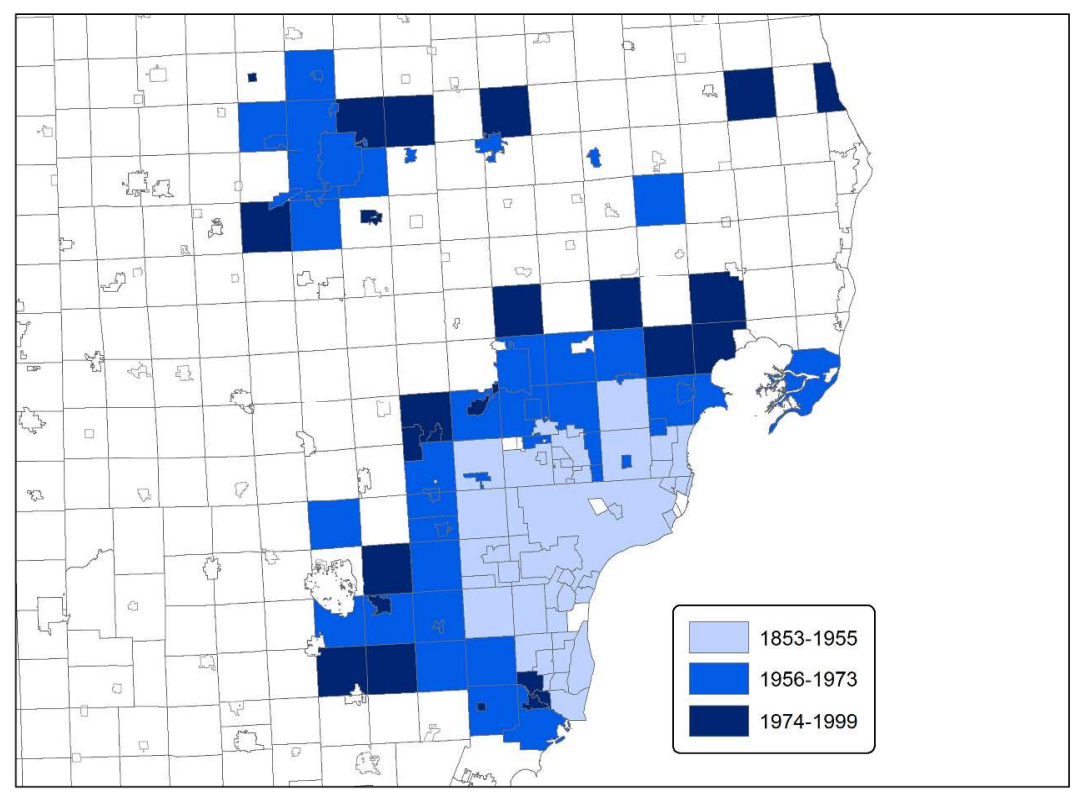

$1164 \times 899 \mathrm{~mm}(72 \times 72$ DPI $)$

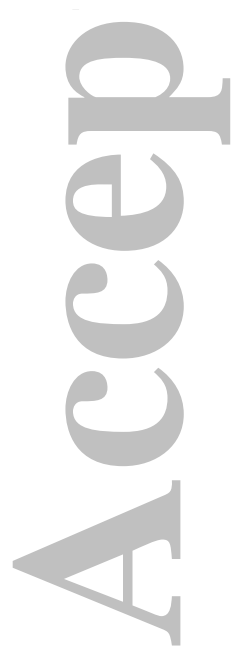

Peer Review Copy

This article is protected by copyright. All rights reserved. 


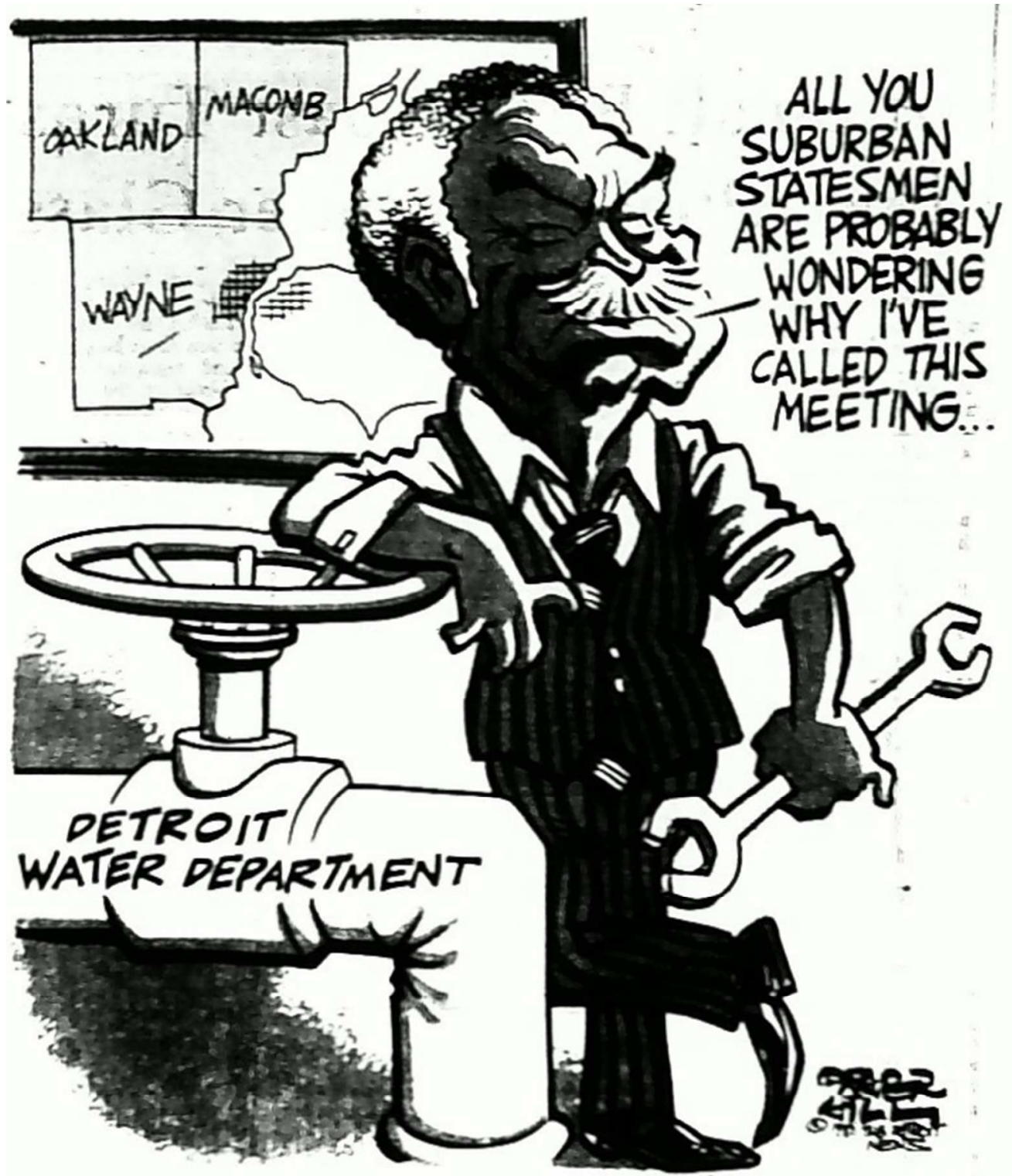

$250 \times 296 m m(72 \times 72$ DPI $)$ 


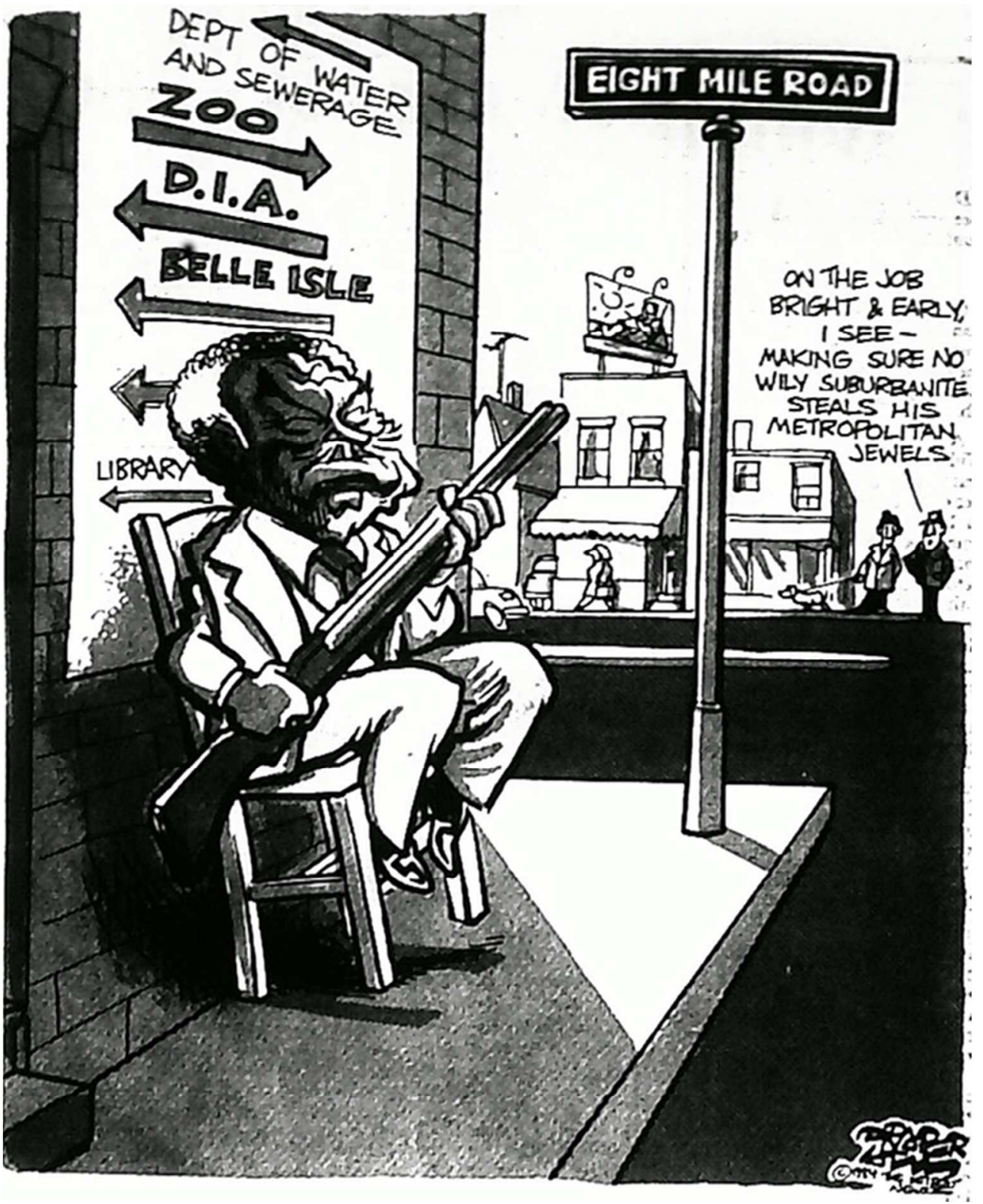

$149 \times 183 \mathrm{~mm}(120 \times 120 \mathrm{DPI})$ 
1.

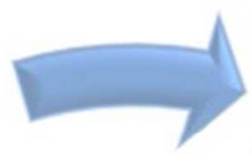

City leaders assert authority

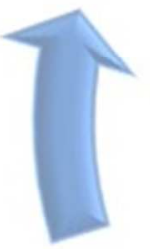

4.

Suburban leaders label city aggressive
2.

Suburban leaders organize against city

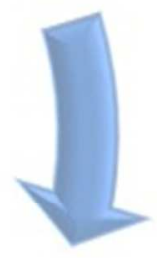

3.

City leaders defend sovereignty

$182 \times 130 \mathrm{~mm}(72 \times 72 \mathrm{DPI})$

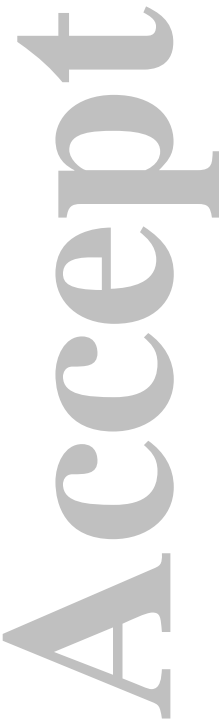


Figure 1: Detroit Water System expansion before, during, and after Gerald J. Remus' tenure by municipality and year joined.
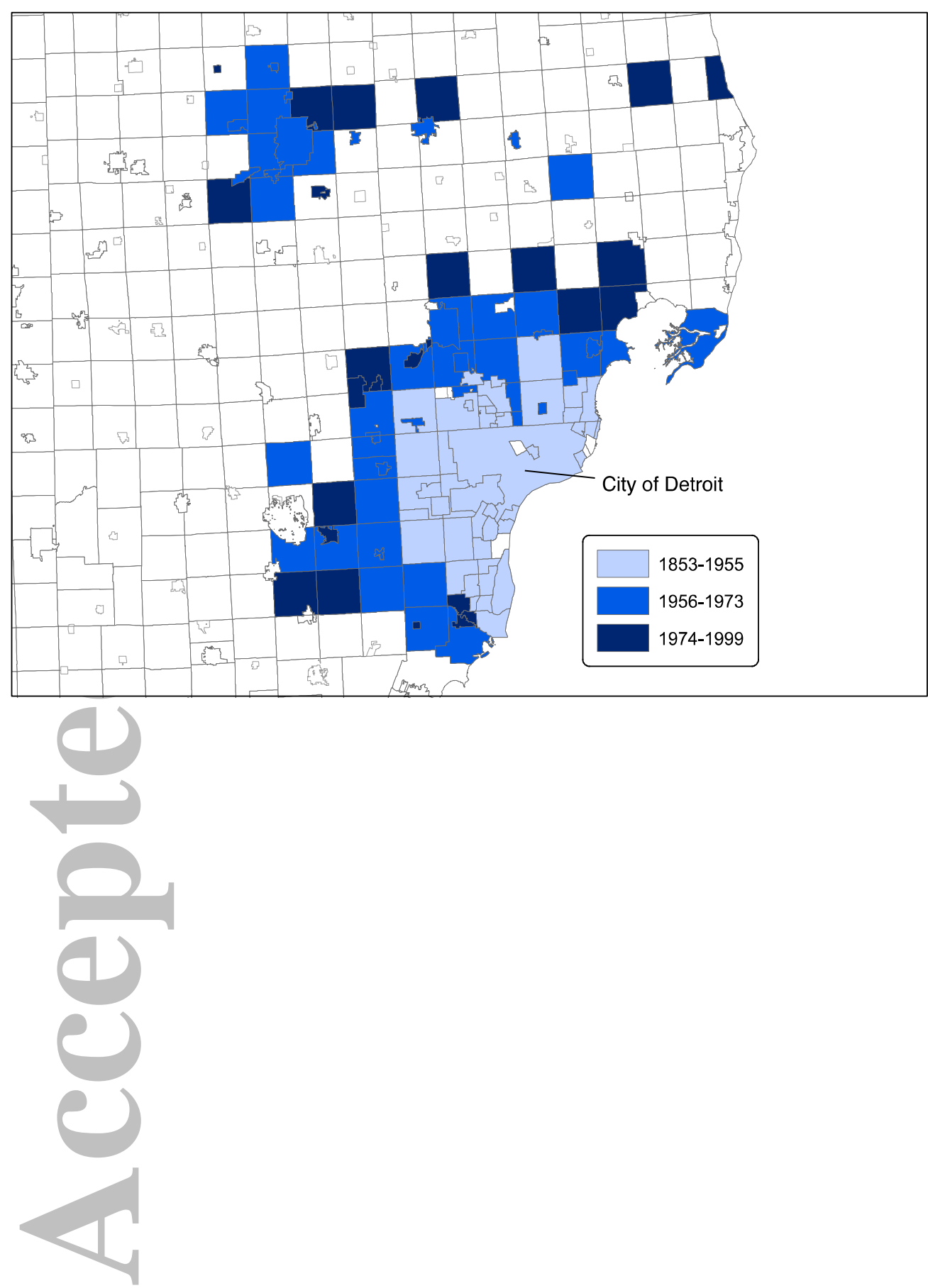
Figures 2 and 3: Political cartoons depicting Detroit's first African American mayor, Coleman Young, as aggressively protecting the city's authority over the water department from neighboring suburban counties.

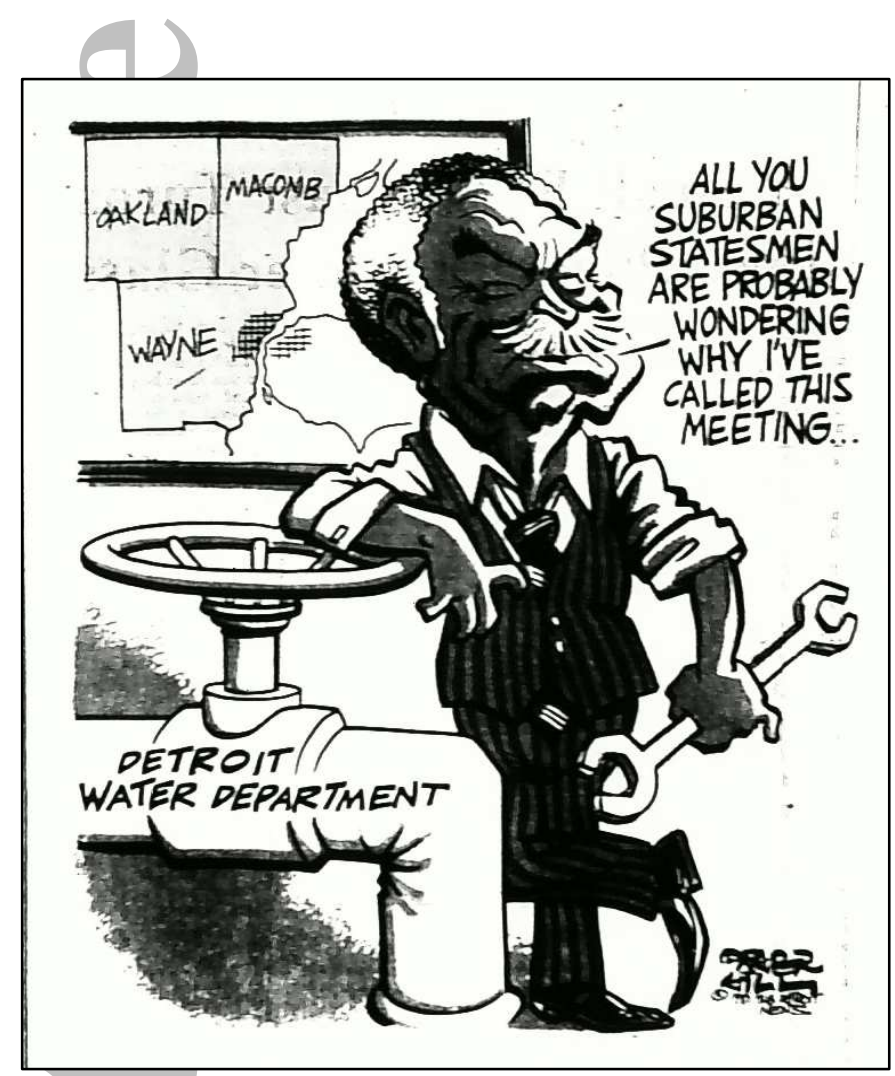

Draper Hill, Detroit News, June 4, 1981, A18

Permission to re-print obtained from the Detroit News.

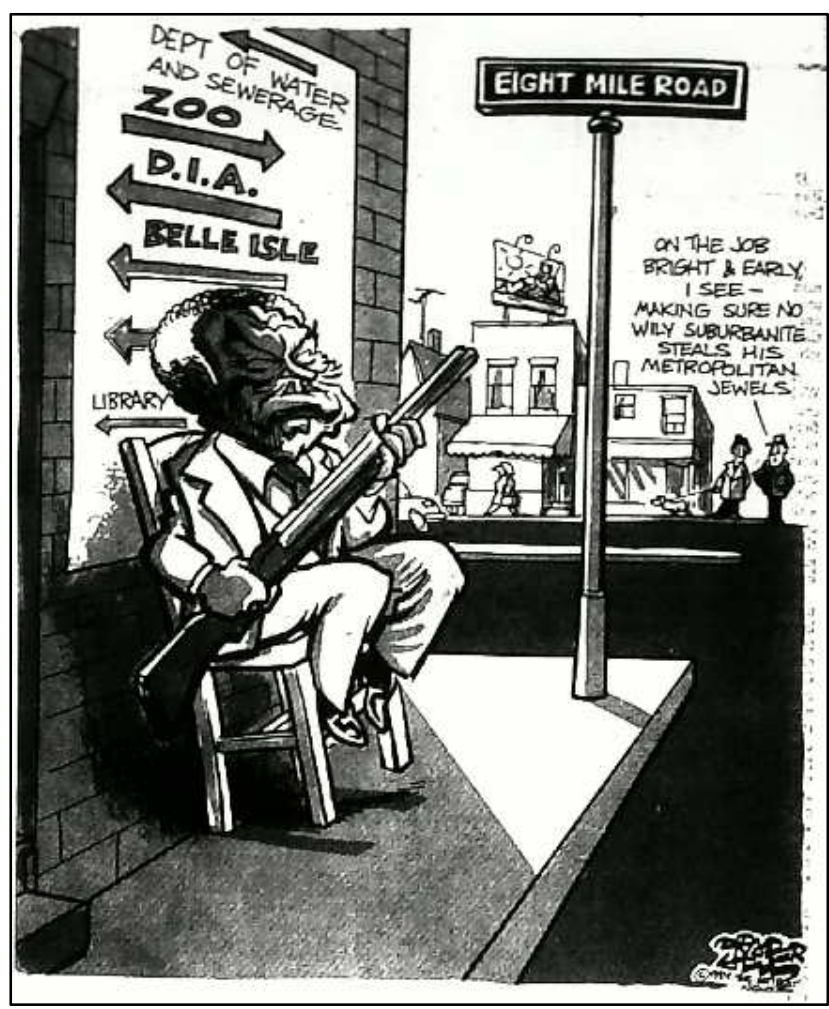

Draper Hill, Detroit News, March 14, 1984, A10 
Figure 4: The vicious cycle of territorial stigma
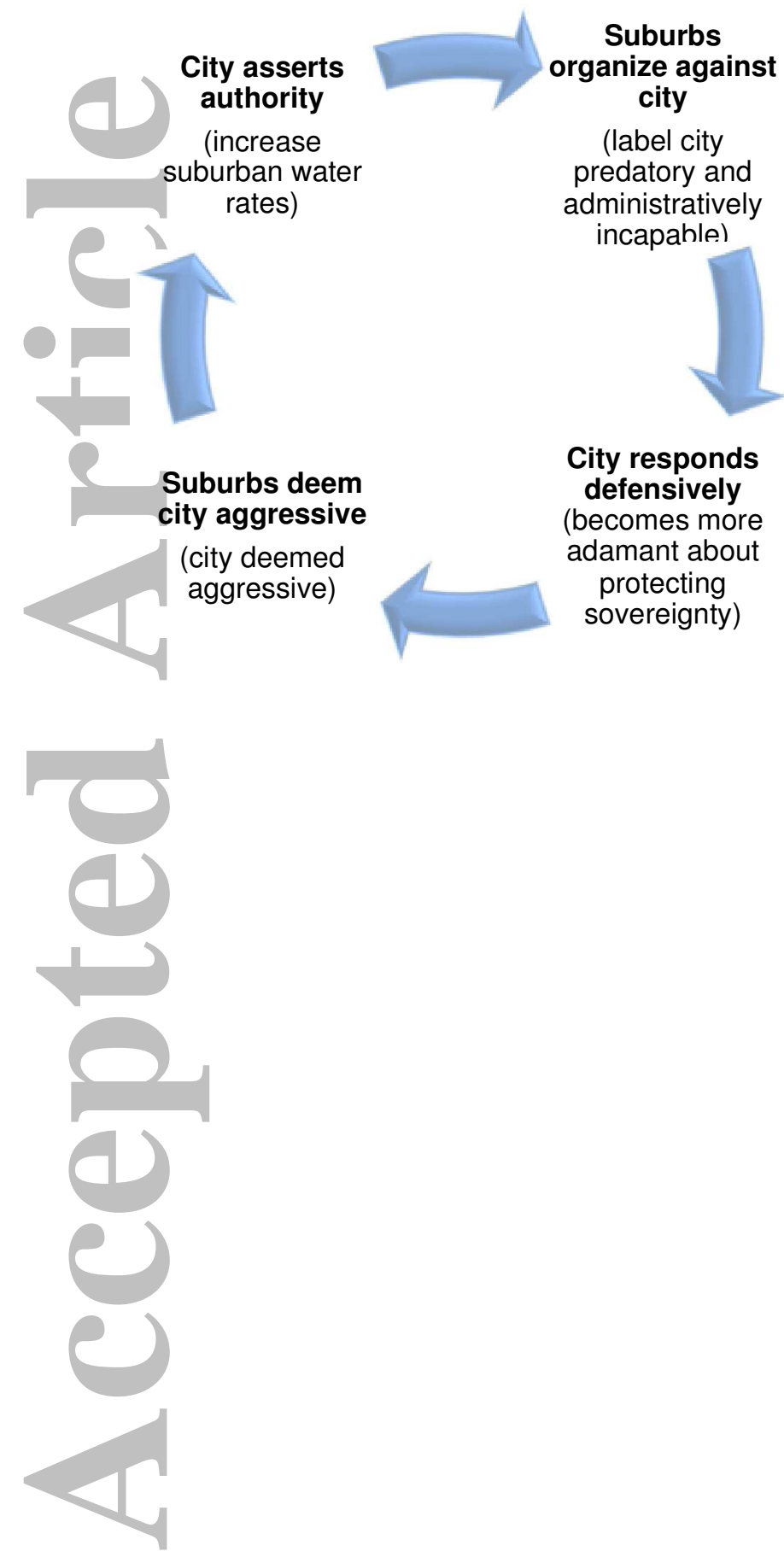